\title{
Histone H2A Type 1-B/E
}

National Cancer Institute

\section{Source}

National Cancer Institute. Histone H2A Type 1-B/E. NCI Thesaurus. Code C162891.

Histone H2A type 1-B/E (130 aa, 14 kDa) is encoded by the human H2AC4 and H2AC8 genes. This protein is involved in chromosome condensation. 